\title{
The preparation and characterization of some metal complexes with tridentate ONO ligand derived from phenyl hydrazine
}

\author{
Mahmoud S. Muter*
}

\author{
Hikmat A. Mohamad**
}

Received 1, March, 2010

Accepted 27, June, 2010

\begin{abstract}
:
The phenyl hydrazine was react readily with acetic acid chloride in [1:2] ratio in alkyl of ethanolic solution, and refluxe for five hours to produce a new ligand of (N-Carboxymethyl-N-phenyl-hydrazino)-acetic acid $\left[\mathrm{H}_{2} \mathrm{~L}\right]$.

This ligand used to synthesize complexes with $\mathrm{Cu}(\Pi), \mathrm{Co}(\Pi), \mathrm{Cr}(\mathbf{I I I})$ and $\operatorname{Pd}(\Pi)$, the structures of some compounds were studied and by Elemental analyses (C $\mathrm{H} \mathrm{N}$ ), IR, UV-Visible and ${ }^{1} \mathrm{C}{ }^{13} \mathrm{H}-\mathrm{NMR}$ spectra, as well as molar conductance measurements, magnetic susceptibility data, and melting point. According to These studies the suggested structure was spin-paired octahedral for the prepared complexes, except the structure of palladium complex was square planar around $\operatorname{Pd}(\Pi)$ ion.
\end{abstract}

\section{Key words: complexes of hydrazine derivatives}

\section{Introduction:}

Hydrazine derivatives with alkanoic[1] and aromatic carboxylic acid[2], play very important role in biological activities, like anticancer[3], anti-inflammatory[4], anti-infective [5], antituberculosis[6].

Depending on the synthesis and biological evaluation of ethyl 2-benzo [1,2,3 triazole] acetate[7], and oxadiazole derivatives[1,8] such [5-(4phenylpiperazin-1-ylmethyl)-1,3,4oxadiazole-2-ylsulfanyl]-acetic acid[6], some hydrazine derivatives can be used to prepared new ligand containing ON donor atoms that have interesting class of compounds, which find an extensive applications in various fields $[9,10]$.

The oxygen and nitrogen may be involved in coordination providing a useful model for bioinorganic processes[11,12]. These compounds are also of interest due to their pharmaceutical applications and biological activities[9,10,13]. In the present work we reported the synthesis and characterization of some complexes with (N-carboxymethyl-Nphenyl-hydrazino)- acetic acid $\left[\mathrm{H}_{2} \mathrm{~L}\right]$.

\section{Materials and Methods:}

\section{Materials:}

Analar or equivalent grade chemicals commercially available from $\mathrm{BDH}$, Merck and Aldrich etc, were used for synthesis.

\section{Instruments:}

1. Melting or decomposition points were measured using Electrothermal 9100 (U.K).

2. IR spectra were recorder as $\mathrm{KBr}$ discs in the range of $(4000-400) \mathrm{cm}^{-}$ ${ }^{1}$ using Shimadzu 8300 FTIR spectrophotometer.

3. Elemental analyses $(\mathrm{C}, \mathrm{H}, \mathrm{N})$ were carried out using Heraeus instrument (Vario EL). AL al. Bayt University. Jordan.

\footnotetext{
*Department of Basic Science, College of Dentistry, University of Anbar, Iraq.

**Education of Science College, Department of Chemistry, University of Salahaddin, Erbil.
} 
4. ${ }^{1} \mathrm{H}$, and ${ }^{13} \mathrm{C}$ NMR were recorded on a DXP-400 $\mathrm{MHz}$ Bruker spectrophotometer (England). AL al. Bayt University. Jordan.

5. UV-Vis spectra were recorded on data steam - (3000) series. Anbar University.

6. Moler conductivity of the complexes of $\left(10^{-3}\right) \mathrm{M}$ was determined using Jenway conductivity meter 4200(0.93) cell constant (U.K).

7. The magnetic susceptibilities of the complexes were determined at $25^{\circ} \mathrm{C}$ using Bruker magnet $\mathrm{BM}_{6}$.

\section{Synthesis:}

3.1. preparation of Carboxymethyl-Nhydrazino)-acetic acid $\left[\mathrm{H}_{2} \mathrm{~L}\right]$

A solution of $\mathrm{KOH}(0.12 \mathrm{gm}, 2.1$ mmol) in ethanol, was added to a solution of phenyl hydrazine (1 gm, $9.24 \mathrm{mmol})$ in hot ethanol $(25 \mathrm{ml})$. The resulting mixture was refluxed on a water-bath for (30) minutes. A quantity of $(1.74 \mathrm{gm}, 18.48 \mathrm{mmol})$ of acetic acid chloride $\left(\mathrm{ClCH}_{2} \mathrm{COOH}\right)$ was added to the above solution and the refluxing was continued for 5 hours [6].

The resulting solution was concentrated and allowed to cool. The separated readish brown product was filtered, further purified by recrystallization from ethanol, dried under vacuum. Yield (0.76 gm) (63.07\%), m.p $\left(108^{\circ} \mathrm{C}\right)$.

3.2. Preparation of $K_{2}\left[\mathrm{Cu}(L)_{2}\right]$ complex

The solution of copper(II) dichloride Hexahydrate (0.27 gm, 1.1 mmol) in methanol was added slowly with stirred to a solution of ligand $\left[\mathrm{H}_{2} \mathrm{~L}\right] \quad(0.5 \mathrm{gm}, 2.05 \mathrm{mmol})$ and potassium hydroxide $(0.24 \mathrm{gm}, 4.2$ mmol $)$ in $(50 \mathrm{ml})$ methanol. The resulting mixture was refluxed for 4 hours on a water-bath and deep green coloured compound separated out on cooling. It was filtered, dried in vacuum. Yield $(65 \%)$ and m.p $\left(140{ }^{\circ} \mathrm{C}\right)$.

\subsection{Preparation of $\mathrm{K}_{2}\left[\mathrm{Co}(\mathrm{L})_{2}\right]$, $\mathrm{K}\left[\mathrm{Cr}(\mathrm{L})_{2}\right]$ and $\mathrm{K}[\operatorname{pd}(\mathrm{L}) \mathrm{Cl}]$ complexes}

A similar method to that mentioned in preparation of $\mathrm{K}_{2}\left[\mathrm{Cu}(\mathrm{L})_{2}\right]$ complex was used to prepare the complexes of $\mathrm{Co}^{\mathrm{II}}, \quad \mathrm{Cr}^{\mathrm{III}}$ and $\mathrm{Pd}^{\text {II }}$ ions with $\left[\mathrm{H}_{2} \mathrm{~L}\right]$ by used $(0.26 \mathrm{gm}, 1.09 \mathrm{mmol}),(0.2$ $5 \mathrm{gm}, 0.93 \mathrm{mmol})$ and $(0.19 \mathrm{gm}$, $1.07 \mathrm{mmol})$ of $\left[\mathrm{CoCl}_{2} \cdot 6 \mathrm{H}_{2} \mathrm{O}\right], \quad\left[\mathrm{CrCl}_{3}\right.$ $\left..6 \mathrm{H}_{2} \mathrm{O}\right]$ and $\left[\mathrm{PdCl}_{2}\right]$ respectively.

\section{Results and Discussion:}

\section{Synthesis and characterization of $\left[\mathrm{H}_{2} \mathrm{~L}\right]$}

The new ligand (NCarboxymethyl-N-phenyl-hydrazino)acetic acid $\left[\mathrm{H}_{2} \mathrm{~L}\right]$ was synthesized according to the general method shown in Scheme (1).

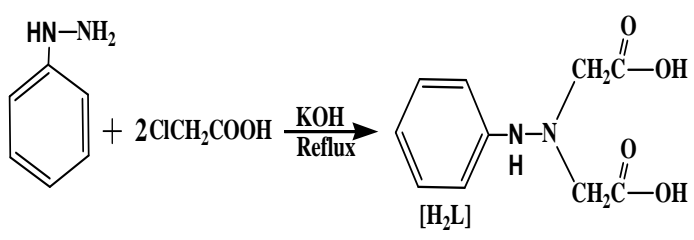

Scheme (1) Synthesis route of the $\left[\mathrm{H}_{2} \mathrm{~L}\right]$ ligand

The ligand was characterized by elemental analysis, Table (1) in which the results were in a good agreement with the calculated values, as well as spectroscopic methods (IR), (UV-Vis), $\left({ }^{1} \mathrm{H},{ }^{13} \mathrm{C}\right) \mathrm{NMR}$.

The prepared ligand was Readish-brown crystals and soluble in different solvent (methanol, ethanol, DMF, DMSO and $\mathrm{C}_{6} \mathrm{H}_{6}$ ) . 
Table (1) Micro analysis and some physical properties for the ligand $\left[\mathrm{H}_{2} \mathrm{~L}\right]$

\begin{tabular}{|c|c|c|c|c|c|c|c|}
\hline \multirow{2}{*}{ Compound } & \multirow{2}{*}{ M.Wt } & \multirow{2}{*}{ Yield (\%) } & \multirow{2}{*}{$\mathbf{M} . P^{\circ} \mathbf{C}$} & \multirow{2}{*}{ Colour } & \multicolumn{3}{|c|}{ Micro analysis found (calc) \% } \\
\hline & & & & & $\mathbf{C}$ & $\mathbf{H}$ & $\mathrm{N}$ \\
\hline$\left[\mathrm{H}_{2} \mathrm{~L}\right]$ & 224 & 63 & 107-109 & Readish-brown & $\begin{array}{c}(4.46) \\
4.18\end{array}$ & $\begin{array}{c}(5.35) \\
5.42\end{array}$ & $\begin{array}{c}(0.89) \\
1.00\end{array}$ \\
\hline $\mathrm{K}_{2}\left[\mathrm{Cu}(\mathrm{L})_{2}\right]$ & 585.5 & 65 & 140 & Deep green & $\begin{array}{l}(40.9) \\
40.88\end{array}$ & $\begin{array}{c}(3.41) \\
3.33\end{array}$ & $\begin{array}{l}(9.56) \\
10.76\end{array}$ \\
\hline $\mathrm{K}_{2}\left[\mathrm{Co}(\mathrm{L})_{2}\right]$ & 581 & 80 & 122 & Deep-purple & $\begin{array}{c}(41.30) \\
40.10\end{array}$ & $\begin{array}{c}(3.44) \\
3.31\end{array}$ & $\begin{array}{l}9.63) \\
10.30 \\
\end{array}$ \\
\hline $\mathrm{K}\left[\mathrm{Cr}(\mathrm{L})_{2}\right]$ & 535 & 71 & 177 & Yellowish-green & $\begin{array}{c}(44.8) \\
44.6 \\
\end{array}$ & \begin{tabular}{|l|}
3.73 \\
3.07 \\
\end{tabular} & $\begin{array}{l}10.46 \\
10.29 \\
\end{array}$ \\
\hline $\mathrm{K}[\mathrm{Pd}(\mathrm{L}) \mathrm{Cl}]$ & 402.8 & 66 & 214 & Deep brown & $\begin{array}{c}(29.79) \\
26.37\end{array}$ & $\begin{array}{c}(2.48) \\
2.44\end{array}$ & $\begin{array}{c}(6.95) \\
6.55\end{array}$ \\
\hline
\end{tabular}

(Calc). Calculated.

\section{Infrared spectra}

Important infrared bands of the ligand $\left[\mathrm{H}_{2} \mathrm{~L}\right]$ and it's complexes together with their assignments are collected in Table (2).

IR spectra of the free ligand, Fig (1), showed a broad band at $(3241) \mathrm{cm}^{-1}$, which is due to hydrogen bonding of $\mathrm{OH}$ group. The interaction with $v(\mathrm{~N}-\mathrm{H})$ stretching[9], Scheme (2-
$\mathrm{A}$ and $\mathrm{B})$. The bands appeared at 1312 and $1243 \mathrm{~cm}^{-1}$ are due to hydrazinic $v(\mathrm{~N}-\mathrm{N})$ and carboxymethyl imine $\mathrm{v}(\mathrm{C}-$ $\mathrm{N})$ stretching of ligand $\left[\mathrm{H}_{2} \mathrm{~L}\right][1]$. A nother bands observed at (3029), (2912), (1677) and (1497) $\mathrm{cm}^{-1}$ assigned to $v(\mathrm{C}-\mathrm{H})_{\text {Arom }}, v(\mathrm{C}-\mathrm{H})_{\text {Aliph }}$, $\mathrm{v}(\mathrm{C}=\mathrm{O}) \quad$ and $\quad \delta(\mathrm{N}-\mathrm{H})$ respectively[10,11].<smiles>O=C(O)C[N+]1(Nc2ccc(C=CCI3OC(=O)C[N+]3(CC(=O)O)CC(=O)O)cc2)COC(=O)C1</smiles>

\section{Scheme (2- A, B) structure of ligand $\left[\mathrm{H}_{2} \mathrm{~L}\right]$}

In the spectra of $\left[\mathrm{H}_{2} \mathrm{~L}\right]$ complexes, the broad band due to hydrogen bonded $\mathrm{OH}$ of the ligand disappeared from the region $(3241) \mathrm{cm}^{-}$ 1 , and showed weak bands at (3440, $3401,3420$ and 3429$) \mathrm{cm}^{-1}$ attributed to the $\mathrm{v}(\mathrm{N}-\mathrm{H})$ stretching of the complexes $\left[\mathrm{Cu}(\mathrm{L})_{2}\right],\left[\mathrm{Co}(\mathrm{L})_{2}\right]\left[\mathrm{Cr}(\mathrm{L})_{2}\right]$ and $[\mathrm{Pd}(\mathrm{L})]$ respectively, indicating the deprotonation and formation of metal oxygen bond. Consequently the $v(\mathrm{C}=\mathrm{O})$ stretching was increased to higher frequency, whilst the $v(\mathrm{C}-\mathrm{O})$ stretching was decreased to lower frequency confirming the coordination of oxygen atom[14].

The free ligand exhibits a weak absorption dands at $1595 \mathrm{~cm}^{-1}$ and $1420 \mathrm{~cm}^{-1}$ due to $v_{\text {asym }}(\mathrm{COOH})$ and $v_{\text {sym }}(\mathrm{COOH})$ respectively. While in the complexes these bands shifted to lower frequency and appeared in the range $(1582-1546) \mathrm{cm}^{-1}$ assigned to $v_{\text {asym }}\left(\mathrm{COO}^{-}\right)$and one in the (1359$1353) \mathrm{cm}^{-1}$ assigned to $v_{\text {sym }}\left(\mathrm{COO}^{-}\right)$. This result indicates that carboxylic group is monodentate coordinate [15]. On the other hand, the hydrazinic $v(\mathrm{~N}$ $\mathrm{N}$ ) in the free ligand were shifted to 
higher frequency, while the carboxymethyl imine $v(\mathbf{C}-\mathbf{N})$ shifted to lower frequency for their complexes. This may be due to the increase in the

repulsion between the lone pairs of electrons on the nitrogen atoms due to the complexation via the hydrazinic nitrogen[16].

Table (2) IR data (wave number $v^{-}$) $\mathrm{cm}^{-1}$ of the ligand and it's complexes

\begin{tabular}{|c|c|c|c|c|c|c|c|c|}
\hline Comp. & $v(\mathbf{N}-\mathbf{H})$ & $\begin{array}{c}U\left(\mathbf{C}_{-}\right. \\
\mathbf{H})_{\text {Arom }}\end{array}$ & $\begin{array}{c}v(\mathbf{C}- \\
\mathbf{H})_{\text {Aliph }}\end{array}$ & $v(C=O)$ & $v(\mathbf{C}=\mathbf{C})$ & $\begin{array}{l}u(\mathbf{N}- \\
\mathbf{N})\end{array}$ & $\begin{array}{l}v(\mathbf{C}- \\
\mathbf{N})\end{array}$ & $\begin{array}{l}\text { Additional } \\
\text { peaks }\end{array}$ \\
\hline$\left[\mathrm{H}_{2} \mathrm{~L}\right]$ & $3241(\mathrm{br})$ & 3029 & 2912 & 1677 & 1600 & 1312 & 1243 & $\begin{array}{l}1497 \delta(\mathrm{N}-\mathrm{H}) \\
1186 \mathrm{v}(\mathrm{C}-\mathrm{O})\end{array}$ \\
\hline $\mathrm{K}_{2}\left[\mathrm{Cu}(\mathrm{L})_{2}\right]$ & 3440 & 3050 & 2887 & 1687 & 1598 & 1317 & 1211 & $\begin{array}{c}1495 \delta(\mathrm{N}-\mathrm{H}) \\
1176 \mathrm{v}(\mathrm{C}-\mathrm{O}) 501 \\
\mathrm{v}(\mathrm{M}-\mathrm{O}) \\
440 \mathrm{v}(\mathrm{M}-\mathrm{N})\end{array}$ \\
\hline $\mathrm{K}_{2}\left[\mathrm{Co}(\mathrm{L})_{2}\right]$ & 3401 & 3041 & 2846 & 1688 & 1604 & 1320 & 1221 & $\begin{array}{l}1498 \delta(\mathrm{N}-\mathrm{H}) \\
1166 \cup(\mathrm{C}-\mathrm{O}) \\
512 \cup(\mathrm{M}-\mathrm{O}) \\
422 \cup(\mathrm{M}-\mathrm{N})\end{array}$ \\
\hline $\mathrm{K}\left[\mathrm{Cr}(\mathrm{L})_{2}\right]$ & 3420 & 3054 & 2874 & 1678 & 1594 & 1332 & 1200 & $\begin{array}{l}1490 \delta(\mathrm{N}-\mathrm{H}) \\
1155 \delta(\mathrm{C}-\mathrm{O}) \\
513 \cup(\mathrm{M}-\mathrm{O}) \\
438 \cup(\mathrm{M}-\mathrm{N}) \\
\end{array}$ \\
\hline $\mathrm{K}[\mathrm{Pd}(\mathrm{L}) \mathrm{Cl}]$ & 3429 & 3059 & 2900 & 1680 & 1597 & 1319 & 1225 & $\begin{array}{c}1493 \delta(\mathrm{N}-\mathrm{H}) \\
1156 \mathrm{v}(\mathrm{C}-\mathrm{O}) 542 \\
v(\mathrm{M}-\mathrm{O}) \\
480 \mathrm{v}(\mathrm{M}-\mathrm{N})\end{array}$ \\
\hline
\end{tabular}

The IR spectra of complexes showed bands at the regions (542-501) and (480-422) $\mathrm{cm}^{-1}$, due to $\mathrm{v}(\mathrm{M}-\mathrm{O})$ and $v(\mathrm{M}-\mathrm{N})$ stretching respectively[10], (were $\mathrm{M}=\mathrm{Pd}, \mathrm{Cu}, \mathrm{Co}$ and $\mathrm{Ni}$ ). The assignment of the bands are summarized in Table (2). Thus from the IR spectra, it is a tridentate fashion through deprotonated of two hydroxyl oxygen and the nitrogen of hydrazine moiety, Scheme (2).

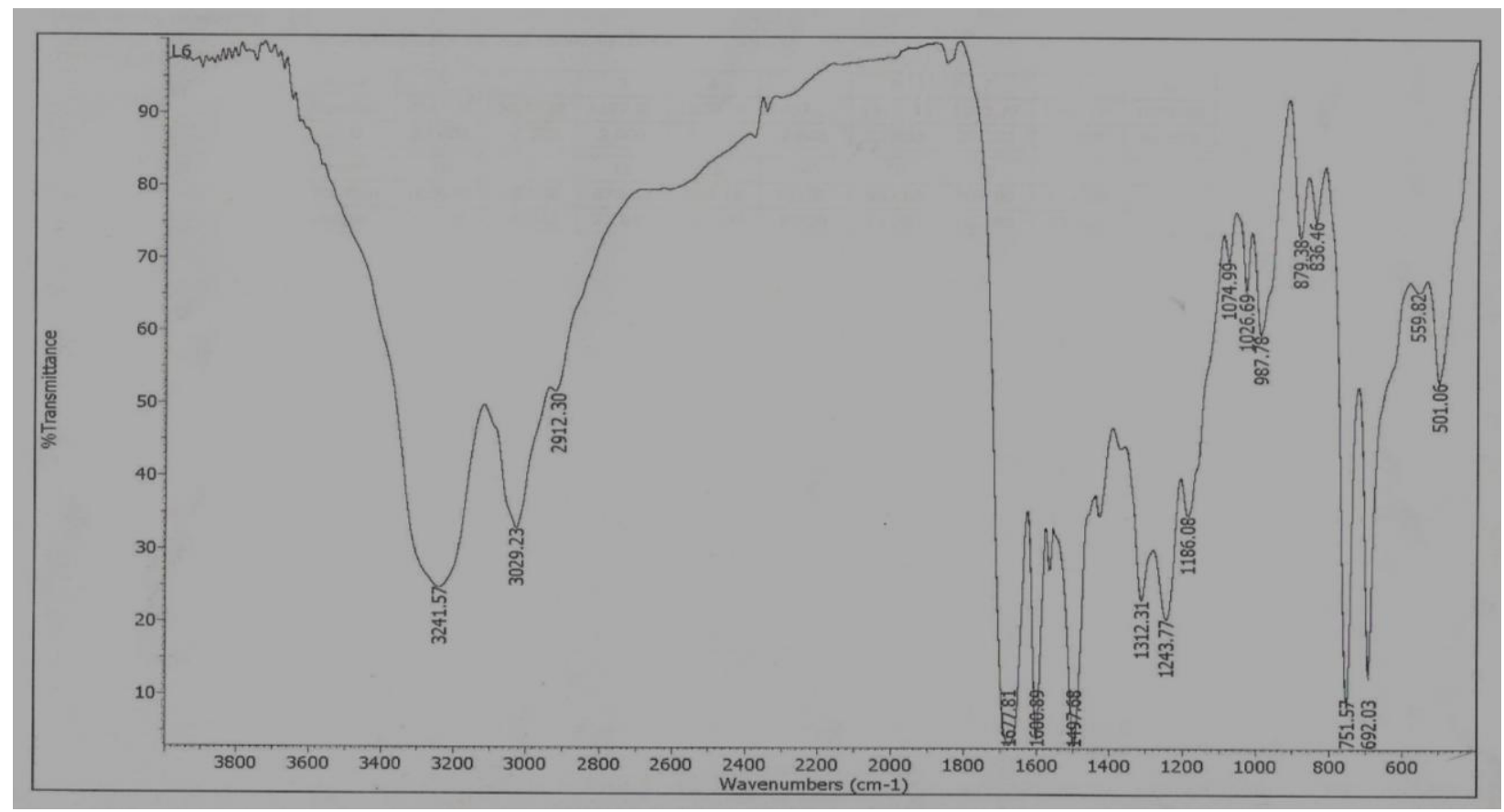

Fig (1) Infrared spectrum of $\left[\mathrm{H}_{2} \mathrm{~L}\right]$ ligand 


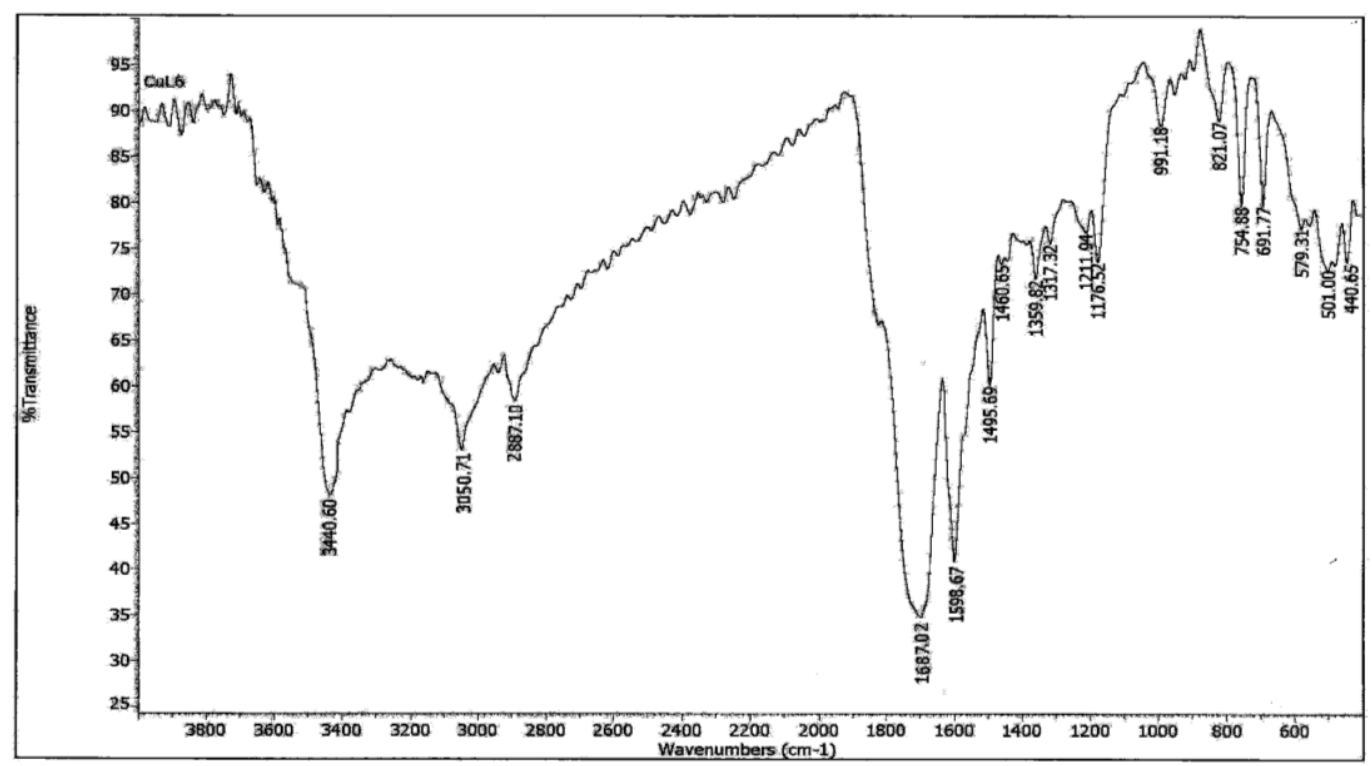

Fig (2) The IR spectrum of $K_{2}\left[\mathrm{Cu}(\mathrm{L})_{2}\right]$ complex

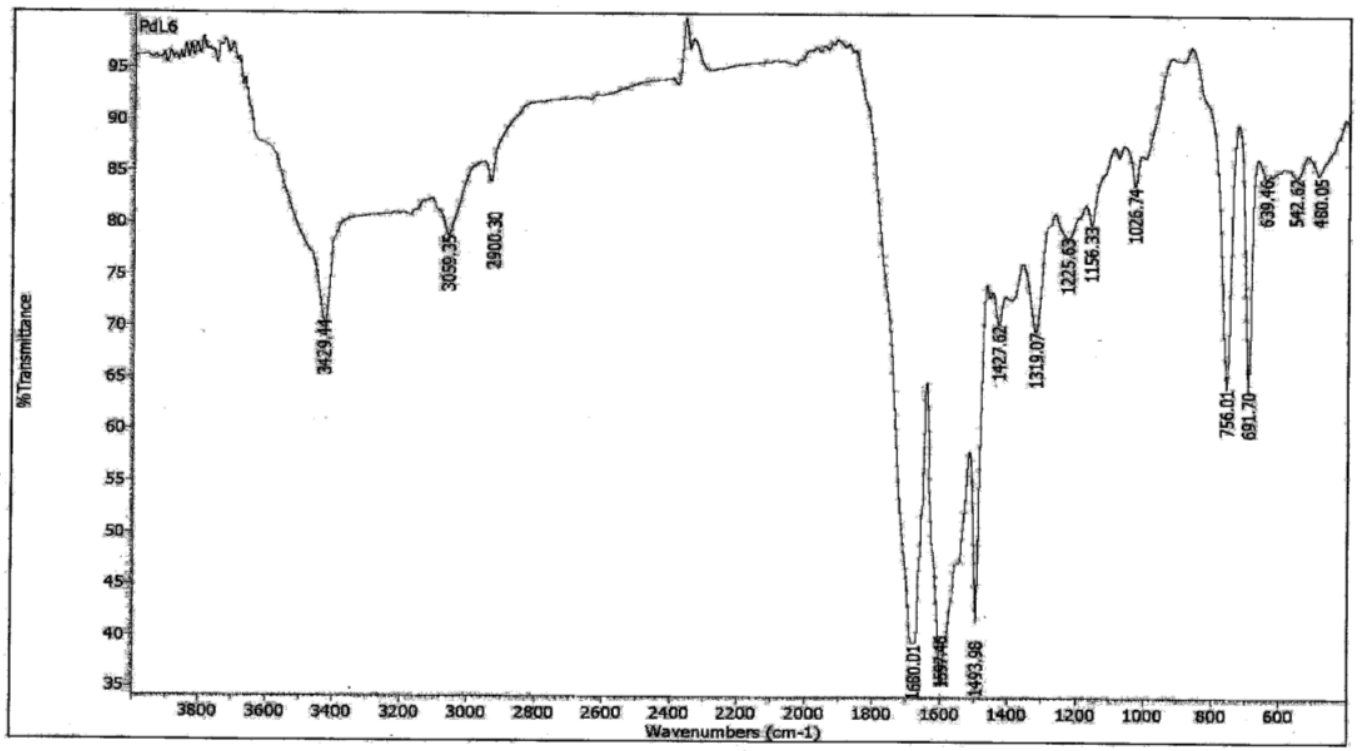

Fig (3) The IR spectrum of $K[P d(L) C l]$ complex

2. Electronic spectra, magnetic moments, conductivity

\section{measurements}

The electronic spectrum of $\left[\mathrm{H}_{2} \mathrm{~L}\right]$ Fig (4) exhibits an entense absorption band at $279 \mathrm{~nm}$ assigned to $\left(\pi \rightarrow \pi^{*}\right), 357 \mathrm{~nm}$ attributed to $\left(\mathrm{n} \rightarrow \pi^{*}\right)$ and weak band at $620 \mathrm{~nm}$ attributed to charge transfer transition. The spectra of the complexes of $\left[\mathrm{H}_{2} \mathrm{~L}\right]$ displayed peeks in the (UV) region of the intraligand $\left(\pi \rightarrow \pi^{*}\right)$ transition, and shifted to higher by various extents in comparison with that in free ligand, while the bands related to charge transfer transitions were observed in the spectra of the complexes, Table(3). The electronic spectra of the $\mathrm{Cu}(\Pi)$ and $\mathrm{Cr}$ (III) complexes displayed bands at (598)nm and (612)nm may be attributed to spin allowed $\mathrm{d}-\mathrm{d}$ transitions, type ${ }^{2} \mathrm{~B}_{1} \mathrm{~g} \rightarrow{ }^{2} \mathrm{~B}_{2} \mathrm{~g}$ and ${ }^{4} \mathrm{~A}_{2} \mathrm{~g}(\mathrm{~F}) \quad \rightarrow{ }^{4} \mathrm{~T}_{2} \mathrm{~g} \quad(\mathrm{~F}) \quad\left(v_{1}\right)$ respectively[17], suggesting an octahedral geometry around $\mathrm{Cu}(\Pi)$ and $\mathrm{Cr}($ III) ions. 
The spectrum of the cobalt(II) complex, Fig (5) exhibited weak bands at $490 \mathrm{~nm}$ and $588 \mathrm{~nm}$, arising from charge transfer and $\left({ }^{4} \mathrm{~A}_{1 \mathrm{~g}} \rightarrow{ }^{4} \mathrm{~T}_{1 \mathrm{~g}}\right)$ d-d transition respectively. These observations are compatible with an octahedral geometry around the cobalt(II) ion[18]. The spectrum of $\operatorname{Pd}(\Pi)$ complex shows a band at $417 \mathrm{~nm}$ assigned to the ${ }^{1} \mathrm{~A}_{1} \mathrm{~g} \rightarrow{ }^{1} \mathrm{~B}_{1} \mathrm{~g}$ transition, suggesting a square planar structure, this is in accordance with the results reported by El-Sonbati, et. for palladium complex [19]. The elemental analysis of the complexes, Table (1) was in a good agreement with the calculated values. On the other hand the conductivity of the complexes determined in methanol $10^{-3} \mathrm{M}$ at 25
${ }^{\circ} \mathrm{C}$, Table (3). The molar conductivity of the complexes $\mathrm{Cu}(\Pi)$ and $\mathrm{Co}(\Pi)$ was (124) and (128) S. $\mathrm{cm}^{2}$. mole $\mathrm{m}^{-1}$ respectively, indicating 1:2 electrolyte, while the conductivity of $\mathrm{Cr}($ III) and $\operatorname{Pd}(\Pi)$ complexes was (55.7) and (60.8) S. $\mathrm{cm}^{2}$. mole ${ }^{-1}$ respectively, indicating 1:1 electrolyte [20]. The magnetic susceptibility for complexes were measured at room temperature, Table (3), the magnetic moment of the complexes $\mathrm{Cu}(\Pi), \mathrm{Co}(\Pi)$ and $\mathrm{Cr}(\mathbf{I I I})$ was typical for a high-spin octahedral structure[21], Fig- (6). The low magnetic moment values of $\operatorname{Pd}(\Pi)$ complex as well as the other analytical data, indicate a square planar structure[19,22], Fig (7).

Table (3) Electronic spectral data of the ligand $\left[\mathrm{H}_{2} \mathrm{~L}\right]$ and its complexes

\begin{tabular}{|c|c|c|c|c|c|}
\hline Comp. & $\lambda \mathbf{n m}$ & $\begin{array}{c}\varepsilon_{\max } \\
\operatorname{molar}^{-1} . \mathrm{cm}^{-1}\end{array}$ & Assignment & $\begin{array}{l}\text { molar conductivity } \\
\text { S. } \mathrm{cm}^{2} \cdot \text { mol }^{-1}\end{array}$ & $\begin{array}{c}\text { Magnecity suseaotibility } \\
\text { B.M }\end{array}$ \\
\hline$\left[\mathrm{H}_{2} \mathrm{~L}\right]$ & $\begin{array}{l}279 \\
357 \\
620\end{array}$ & $\begin{array}{c}1982 \\
960 \\
191 \\
\end{array}$ & $\begin{array}{c}\quad \pi \rightarrow \pi^{*} \\
\mathrm{n} \rightarrow \pi^{*} \\
\text { Charge transfer }\end{array}$ & -- & -- \\
\hline $\mathrm{K}_{2}\left[\mathrm{Cu}(\mathrm{L})_{2}\right]$ & $\begin{array}{l}330 \\
365 \\
598\end{array}$ & $\begin{array}{c}1150 \\
1040 \\
60\end{array}$ & $\begin{array}{c}\pi \rightarrow \pi^{*} \\
\text { Charge transfer } \\
{ }^{2} \mathrm{~B}_{1} \mathrm{~g} \rightarrow{ }^{2} \mathrm{~B}_{2} \mathrm{~g}\end{array}$ & 124.6 & 1.32 \\
\hline $\mathrm{K}_{2}\left[\mathrm{Co}(\mathrm{L})_{2}\right]$ & $\begin{array}{l}226 \\
384 \\
490 \\
588\end{array}$ & $\begin{array}{c}1737 \\
752 \\
186 \\
89\end{array}$ & $\begin{array}{c}\pi \rightarrow \pi^{*} \\
n \rightarrow \pi^{*} \\
\text { Charge transfer }{ }^{4} \mathrm{~A}_{1} \mathrm{~g} \rightarrow{ }^{4} \mathrm{~T}_{1} \mathrm{~g}\end{array}$ & 128.2 & 1.42 \\
\hline $\mathrm{K}\left[\mathrm{Cr}(\mathrm{L})_{2}\right]$ & $\begin{array}{l}295 \\
378 \\
612\end{array}$ & $\begin{array}{c}1100 \\
880 \\
26\end{array}$ & $\begin{array}{c}\pi \rightarrow \pi^{*} \\
\text { Charge transfer } \\
{ }^{4} \mathrm{~A}_{2} \mathrm{~g}^{(\mathrm{F})} \rightarrow{ }^{4} \mathrm{~T}_{2} \mathrm{~g}^{(\mathrm{F})}\end{array}$ & 55.7 & 3.77 \\
\hline $\mathrm{K}[\mathrm{Pd}(\mathrm{L}) \mathrm{Cl}]$ & $\begin{array}{l}305 \\
370 \\
417\end{array}$ & $\begin{array}{l}988 \\
740 \\
115\end{array}$ & $\begin{array}{c}\pi \rightarrow \pi^{*} \\
\text { Charge transfer } \\
{ }^{1} \mathrm{~A}_{1} \mathrm{~g} \rightarrow{ }^{1} \mathrm{~B}_{1} \mathrm{~g}\end{array}$ & 60.8 & 0.23 \\
\hline
\end{tabular}

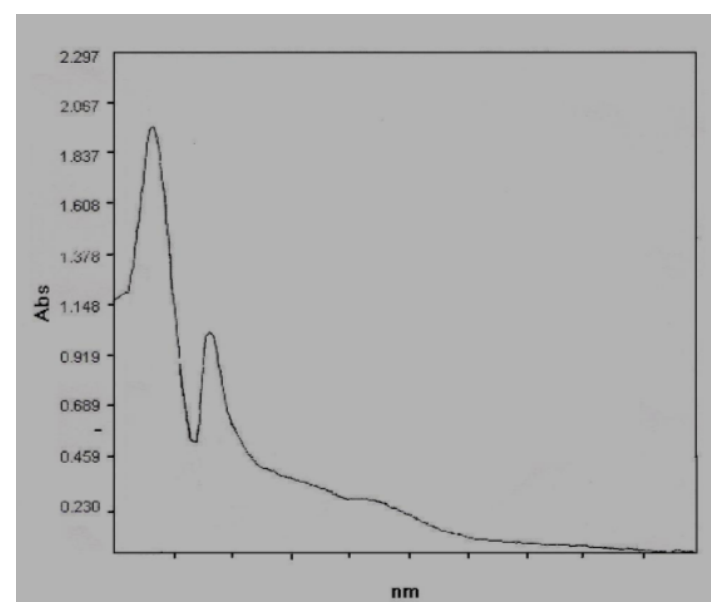

Fig (4) UV-Vis spectrum of $\left[\mathrm{H}_{2} \mathrm{~L}\right]$

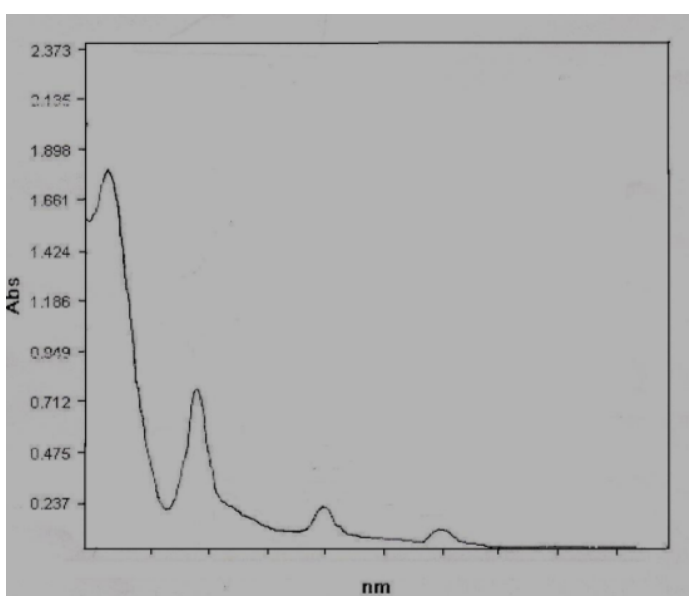

Fig (5) UV-Vis spectrum $\mathrm{K}_{2}\left[\mathrm{Co}(\mathrm{L})_{2}\right]$ 


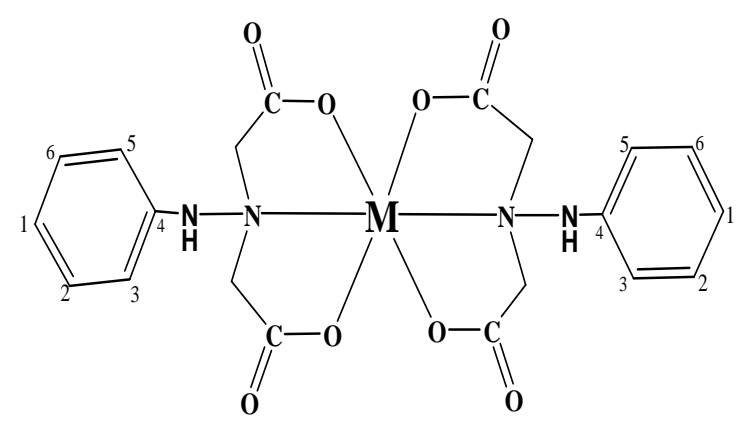

Fig (4) The proposed geometrical structure of $\left[\mathrm{M}(\mathrm{L})_{2}\right]$ compLex (where: $\mathrm{M}=\mathrm{Cu}, \mathrm{Co}$, and $\mathrm{Cr}$ )<smiles>[M]CCNNc1ccccc1</smiles>

Fig (5) The proposed geometrical structure of $\mathrm{K}[\mathrm{Pd}(\mathrm{L}) \mathrm{Cl}]$ complex 3. ${ }^{1} \mathrm{H}^{13} \mathrm{C}$ NMR spectra

The ${ }^{1} \mathrm{H}$ NMR spectra recorded at $400 \mathrm{MHz}$ by using a DMSO-d 6 solvent, are shown in Fig (8) and Table (4). The ${ }^{1} \mathrm{H}$ NMR spectrum for the ligand $\left[\mathrm{H}_{2} \mathrm{~L}\right]$ showed signal at $7.79 \mathrm{ppm}$ $(2 \mathrm{H}, 2 \times \mathrm{OH})$ due to the equivalent protons of $(\mathrm{OH})$ groups, this lower chemical shift of $\mathrm{OH}$ refers to the hydrogen bond [10]. The signal at $7.73 \mathrm{ppm}(1 \mathrm{H}, \mathrm{NH})$ due to proton of $\delta(\mathrm{NH})$, While the band at $2.5 \mathrm{ppm}(\mathrm{S}$, $4 \mathrm{H})$ is due to $\delta\left(\mathrm{CH}_{2}\right)[23]$. ${ }^{1} \mathrm{H} \mathrm{NMR}$ for ligand showed signals for protons of aromatic group between 7.35-6.13 ppm $(\mathrm{m}, 5 \mathrm{H})$.

${ }^{13} \mathrm{C}$ NMR spectrum of the $\left[\mathrm{H}_{2} \mathrm{~L}\right]$ was carried out in DMSO- $\mathrm{d}_{6}$,
Table (4), Fig (9). The spectrum showed a chemical shift at $169.4 \mathrm{ppm}$ assigned to carbon atoms of $\delta(\mathrm{COOH})$ groups[24]. The chemical shift of the phenyl group appeared in the aromatic region at (129.5-112.5) ppm, whilst the carbon atoms of $\delta\left(\mathrm{CH}_{2}\right)$ groups are equivalent and appeared as single at $56.9 \mathrm{ppm}$.

Table (4) The chemical shift in ppm for ${ }^{1} \mathrm{H}{ }^{13} \mathrm{C}$ NMR data of $\left[\mathrm{H}_{2} \mathrm{~L}\right]$ measured in DMSO-d 6 .

\begin{tabular}{|c|c|c|}
\hline Fund.Group & $\begin{array}{c}{ }^{1} \mathbf{H} \\
\text { NMR }(\delta, \\
\text { ppm) }\end{array}$ & $\begin{array}{c}{ }^{13} \mathrm{C} \\
\mathrm{NMR}\left(\delta_{\mathrm{s}},\right. \\
\operatorname{ppm})\end{array}$ \\
\hline $\mathrm{OH}$ & 7.79 & - \\
\hline $\mathrm{NH}$ & 7.73 & \\
\hline$\left(\mathrm{C}_{2}\right) \mathrm{H},\left(\mathrm{C}_{6}\right) \mathrm{H}$ & $\begin{array}{l}7.35, \\
7.25 \\
\end{array}$ & $129.5,129$ \\
\hline$\left(\mathrm{C}_{3}\right) \mathrm{H},\left(\mathrm{C}_{5}\right) \mathrm{H}$ & $6.75,6.6$ & $\begin{array}{l}112.9 \\
112.7\end{array}$ \\
\hline$\left(\mathrm{C}_{1}\right) \mathrm{H}, \mathrm{C}_{4}$ & 7.10 & $\begin{array}{l}119.2 \\
112.5\end{array}$ \\
\hline $\mathrm{CH}_{2}$ & 2.5 & 56.9 \\
\hline $\mathrm{C}=\mathrm{O}$ & - & 169.4 \\
\hline
\end{tabular}

\section{Conclusion:}

We have explored the syntheses and coordination chemistry of some complexes, obtained from reaction of tridentate ligand, derived from phenyl hydrazine $\left[\mathrm{H}_{2} \mathrm{~L}\right]$, Scheme (1), with metal ions $\left(\mathrm{Cu}^{\Pi}, \mathrm{Co}^{\Pi}, \mathrm{Cr}^{\text {III }}\right)$ in [2:1] ratio respectively, and with $\mathrm{Pd}^{\Pi}$ in [1:1] ratio. The mode of bonding and overall structure of the complexes, were determined by physico-chemical and spectroscopy methods. The results revealed that the ligand coordinate with center ion through oxygen atoms of hydroxyl groups and hydrazinic nitrogen as ONO donor atoms. According to the above results, its concluded that the geometry about $\mathrm{Cu}^{\Pi}, \mathrm{Co}^{\Pi}, \mathrm{Cr}^{\text {III }}$ is octahedral, Fig (4), and about $\mathrm{Pd}^{\Pi}$ is square planar, Fig (5). 


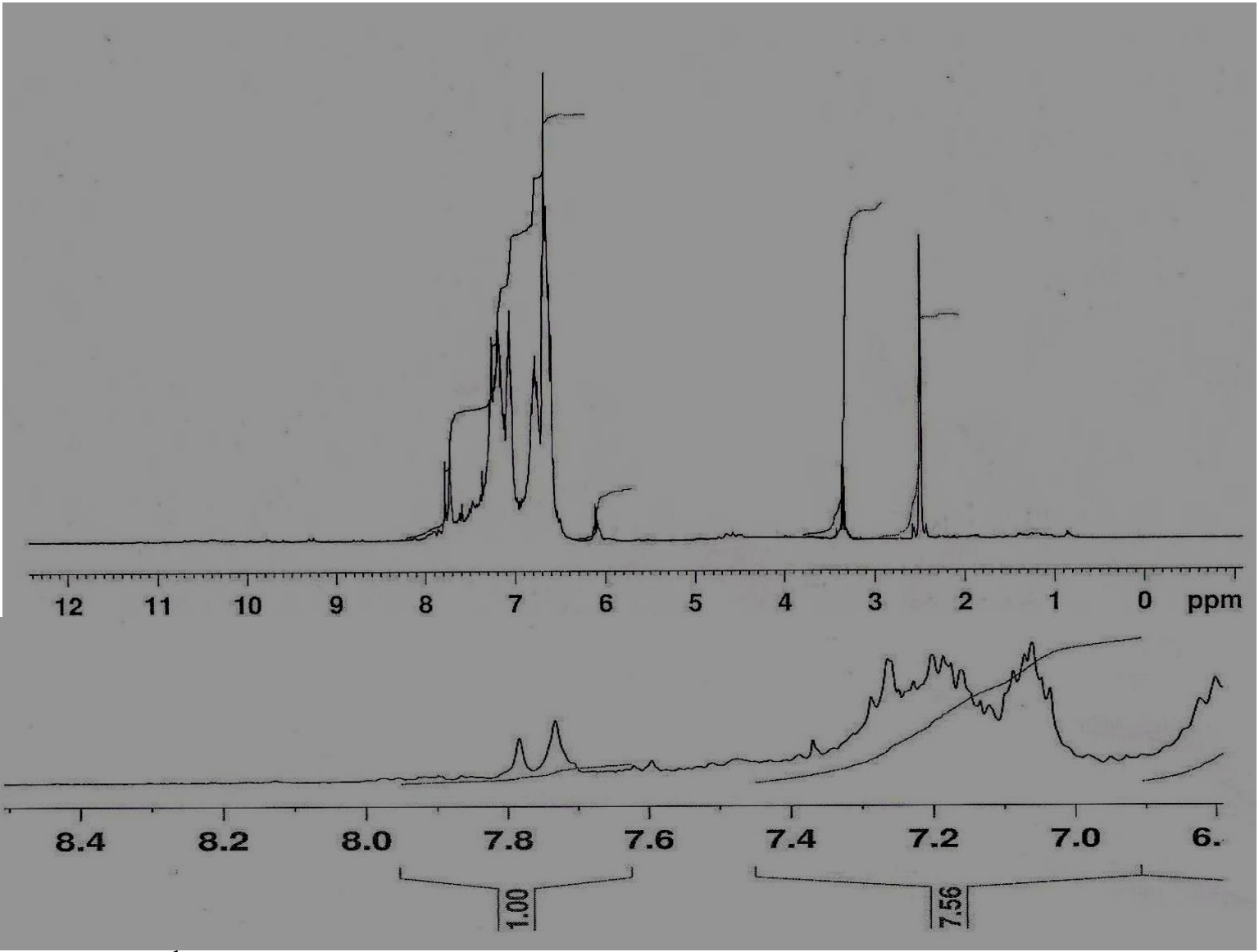

Fig (8) The ${ }^{1} \mathrm{H}$ NMR spectra for ligand $\left[\mathrm{H}_{2} \mathrm{~L}\right]$

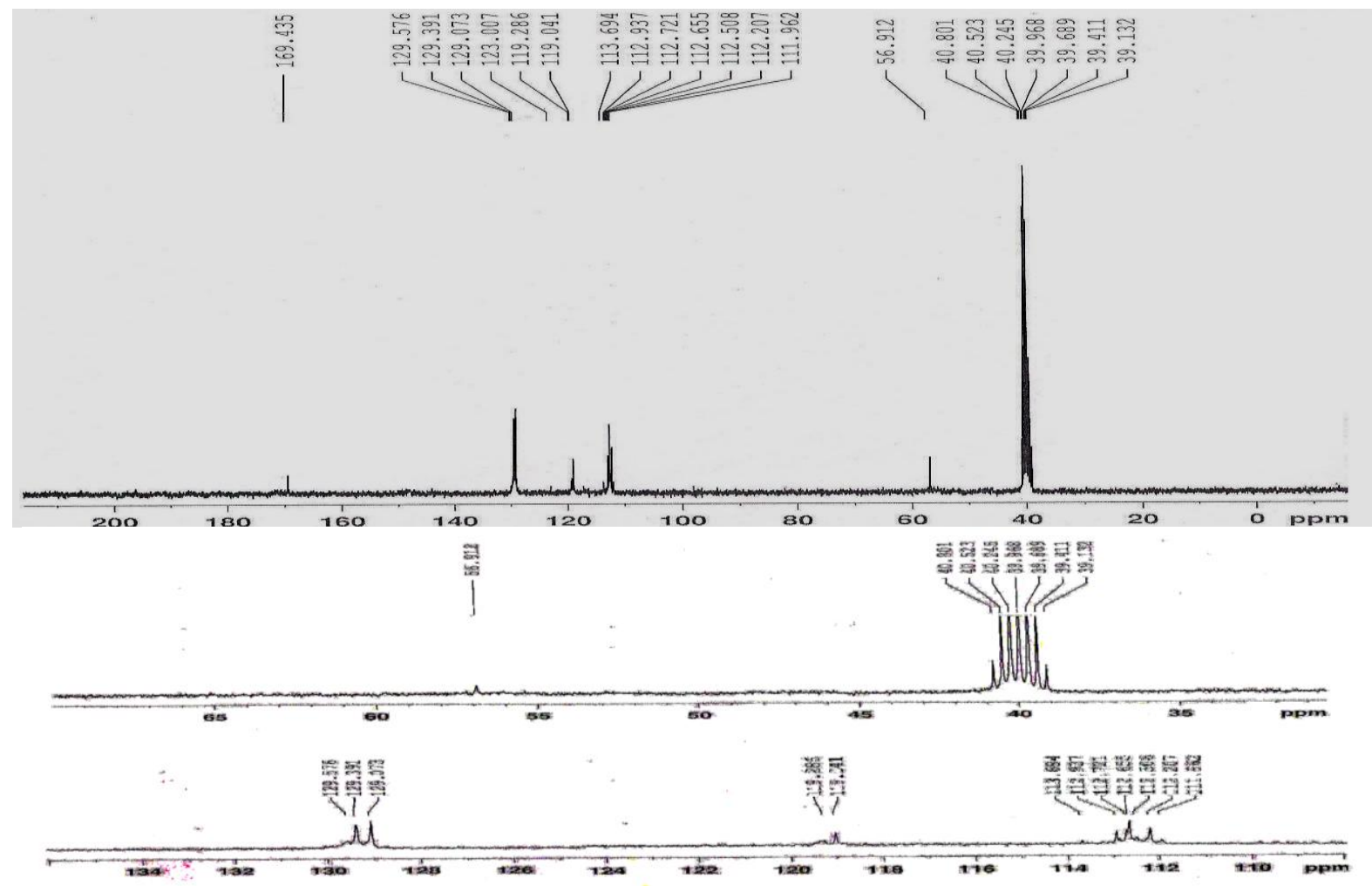

Fig $(9){ }^{13} \mathrm{C}$ NMR spectra for ligand $\left[\mathrm{H}_{2} \mathrm{~L}\right]$ 


\section{References:}

1. Jain,N. Pathak, D.P. Mishra P. and Jain, S. 2009. Synthesis and Antibacterial Studies of Some 2-[5(Aryl)-[1,3,4]oxadiazole-2ylsulfanyl] alcanoic acids., J. Iran. Chem. Soc., 6 (1) : 77-81.

2. Yale, H. Loose, L. K. Martins,J. Holsing, M. Perry, and F.M. Bernstein, J. 1953. Reaction between hydrazine and methyl esters of aromatic carboxylic acids. J. Am. Chem. Soc., 75 : 1933.

3. Aboraia,S. H. Abdel-Rahman, M. Mahfouz, N.M. and EL-Gendy, M.A. 2006. Synthesis and biological studies of Schiff base derivative from aromatic fatty acids., Bioorg. Med. Chem., 14 : 1236.

4. Burbuliene,M.M. Jakubkiene, V. G. Mekuskiene, E. Udrenaite, R. Smicius, P. Vainilavicius, Farmaco., 2004. Anti-inflammatory of 1,3,4-Oxadiazole derivatives, 59 :767.

5. Finch, R., Greenwood, D., Norrby, S.R., Whitley, R. 2003, Antibiotic and chemotherapy, Anti-infective agent and use in therapy. $8^{\text {th }}$ ed., Churchill Livingstone Philadelphia, USA., 1000.

6. Foks, H. D. Pancechowska-Ksepko, Janowiec,M. Zwolska., Z. 2004 .Synthesis, characterization and biological activity of [5-(4phenylpiperazin-1-ylmethyl)-1,3,4oxadiazole-2-ylsulfanyl]-acetic acid., Acta. Poloniae Pharmaceutica-Drug Research. 6: 473.

7. Saini,R. Rai, A.K. Kesari, A.N. Yar., M. S. 2009. Synthesis and biological evaluation of 2,5 disubstituted 1,3,4 oxadiazoles. Asian J. Chem., 2 : 34.

8. Muhi-eldeen,Z. Al-kaissi, E. 2008. Antimicripial Activity of Some New Oxadiazole Derivatices., Jordan J. of Chem., 3(3) :233-243.
9. Murukan,B. Mohanan, K. Studies Some Trivalent Transition Metal Complexes With A bishydrazone., J. Saudi Chem. Soc.,2006. 10(2) :261-270.

10. Jaber Al-Jeboori. M. Al-Dujaili, A. H. Al-Janabi, A. E. Coordination of Carbonyl Oxygen in the $\mathrm{N}$ crotonyl-2-

hydroxyphenylazomethine.,

Transition Met. Chem., 2008, Doi 10. 1007/s11243-008-9165-9..

11. Al-Jeboori, M. J. Al-Fahdawi, M. S. Sameh., A.A. 2009. New Homoleptic Metal Complexes of Schiff bases Derived from 2,4-di-ptolyl-3-Azabicyclo[3.3.1] nonane9-one., J. Coord. Chem., 62(23) :3853-3863.

12. Muter, M. S. Ph.d thesis, college of Education Ibn Al-Haitham, 2006. Synthesis and phescochemical studies of new ligands derived from 2,4-di-p-tolyl-3-Azabicyclo [3.3.1] nonane-9-one with their complexes., University of Baghdad., 205.

13. Bernhardt. P.V. Mattsson,J. Richardson., D.R. 2006. Biological evaluation of bidentate ON ligands of oxodiazol derivative., Inorg. Chem., 45: 752.

14. Mohamed G. G. and Abd ElWahab., Z. H. 2003, Polymeric and sandwich Schiff base complexes derived from 4,4-methyl aniline., J. Therm. Anal. Cal., $73: 347$.

15. Mesubi, M. A. 1982, ,An infrared study of Zinc, Cadmium and lead salt of some fatty acids, Journal of Molecular structure, 81, 2, PP. 6171.

16. West, D.X. Beraldo, H. R. Lima and Teixeira., L. R. 2004., preparation and characterization of cobalt(II) and nickel(II) complexes with Schiff basees J. of Molecular Structure,. $559: 99$ 
17. Lever AMP Inorganic electronic spectroscopic, vol. 2. Elesvier Publishing, New York, 1984.

18. C. K. Jorgensen, 1962. Electronic studies of some complexes with Schiff base ligands J. Inorg. Nucl. Chem., $24: 157$.

19. El-Sonbati AZ, Al-Shihri AS, ElBindary AA, 2004. Studies of transition metal complexes with Oxadiazole derivative., $J$, Inorg. Organometallic Polym., 14: 76.

20. W.J. Geary., 1971. The use of conductivity measurements in organic solvents for the characterization of coordination coumpounds Coord. Chem. Rev., 7 : 81-122.
21. El-Asmy, A.A. El-Metwally, N.M. Abou-Hussen., A.A. 2006. Spectral, Magnetic, electrical and thermal studies on malonyl bis(thiosemicarbazide) complexes. Int. J. Pure Appl. Chem., 1 : 75.

22. Cotton., F. Willkenson., A. G. 1980. Advanced Inorganic Chemistry $4^{\text {th }}$ Edition, J. Willy and Sons 103.

23. El-Sawaf A.K. and Weast., D. X. 1998. NMR Studies of the some organic compounds., Transition Met. Chem., $23: 417$.

24. Awadallah, A.M. 2006. Reaction of Aryl-and Heteroaryl Benzoyland Acetylhydrazones with Phenylisocyanate, Islamic University J., 14 (1): 129-133.

\section{تحضير وتشخيص بعض المعقدات الفلزيه مع ليكند ثلاثي السن مشتق من هايدرازين الفينيل

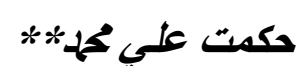

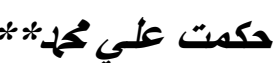 \\ محمود صالح مطر

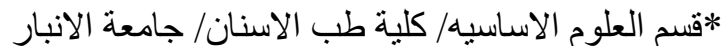

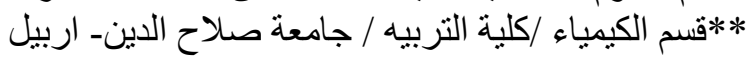

تم مفاعلة هايدرازين الفينيل مع كلوريد حامض الخليك بنسبة (1: 2) في محلول الايثانول القاعدي,

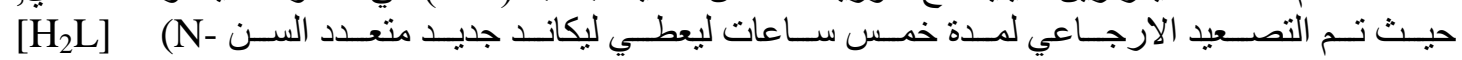
Carboxymethyl-N-phenyl-hydrazino)-acetic acid

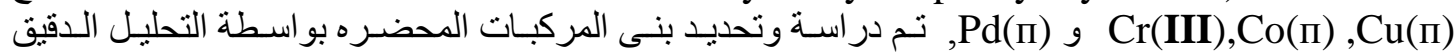

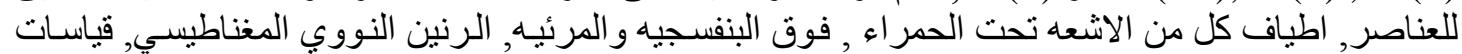

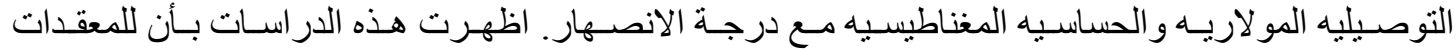

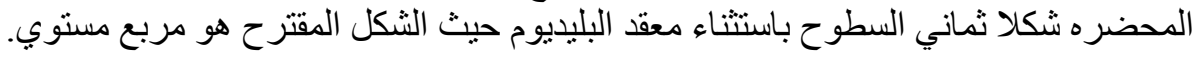

